\title{
Private Law as an Open Legal Order: Understanding Contract and Tort as Interactional Law*
}

\author{
Sanne Taekema
}

\section{Introduction}

In legal and political philosophy, the idea of reciprocity is often discussed in relation to Rawls's claim that reciprocity underpins the principles of justice. ${ }^{1}$ In this contribution to the theme, I will approach reciprocity from a different direction, by examining how reciprocal relations figure in two main areas of private law. I will argue that contract and tort, as two central areas of law, show that important parts of law are interactional: they depend on the moral norms that are implicit in social practices rather than on formal legal rules. Making use of Lon Fuller's interactionism, I develop the idea that law as a whole cannot be seen as a completely formal system, but is interactional in certain key aspects. Before I sketch out my argument, I will present a Dutch tort case, which may set the scene for the theoretical argument.

In 2004, a woman goes to the office of a notary to have a document passed. After her appointment, she needs to visit the toilet and asks for its location. The notary tells her that it is located in a corridor of the office. In search of the right room, the woman opens one of the doors in the corridor. She steps through the door and, instead of finding a toilet, falls down the steps behind it into a cellar. The steps started directly behind the door, and there was no light on. The railing of the steps was on the left wall, while the light switch was on the right. She breaks a neck vertebra, her wrist and numerous teeth. The damage to her neck and shoulders results in a permanently reduced ability to move. The woman brings an action before the court on the basis of tort, arguing that the notary's office had not taken the care to be expected. The court holds the notary liable because the notary had not taken very simple precautionary measures, like a lock on the cellar door or a signs such as 'cellar' or 'do not enter,' which could have prevented incautious visitors from entering the cellar and being placed in a dangerous situation. ${ }^{2}$

* Many thanks to participants and lecturers of the Summer Course on Reciprocity for their comments on an oral presentation of a previous version, and to the two anonymous reviewers for their criticisms and suggestions.

1 John Rawls, 'Justice as Reciprocity,' in John Rawls, Collected Papers, ed. Samuel R. Freeman (Cambridge, MA: Harvard University Press, 1999), 190-224.

2 Court of Appeal 's-Hertogenbosch 6 April 2010, ECLI:NL:GHSHE:2010:BM0971. Most of the examples in the article are taken from Dutch law, for the simple reason that this is the legal system which I know best. I have included some references to non-Dutch cases to indicate that the argument can be generalized. 
Courts deal with such cases routinely. What they do is not so much to apply a legal rule, based on statute or precedent, but to assess what people in the particular situation could reasonably expect from each other. My claim therefore is that in these parts of private law (the same argument holds for contract, as I will show later) there is an open flow between the formal law of legislature and courts and the social interactions of people in ordinary life. Most importantly, the legal assessment of cases of tort and contract is largely based on the normative force of interactional expectancies.

\section{The theoretical background: pragmatist interactionism}

My approach to these problems is not neutral. The theoretical inspiration for my approach lies in the (socio-)legal philosophy of Lon Fuller and Philip Selznick, and the philosophy of classical pragmatism. ${ }^{3}$ In what I would like to call pragmatist interactionism, ${ }^{4}$ reasoning such as that of the court mentioned in the introduction fits an idea of law as continuous with people's everyday social practices. The main idea of interactionism is that legal norms arise out of the social interactions between ordinary people. In their day-to-day activities people continually shape their conduct in relation to what they expect others to do and to what others expect of them. As Fuller explains in 'Human Interaction and the Law': 'To engage in effective social behavior men need the support of intermeshing anticipations that will let them know what their opposite numbers will do (...). ${ }^{5}$ Predictability of behaviour is important because it enables people to plan their own activities. Legal norms play an important role by stabilizing such expectations. It is not necessary for such stability that norms are explicit. Shared implicit norms are equally capable of making behaviour predictable. It is crucial, however, that they give rise to mutual expectations; rules that are kept by only one individual do not constitute legal norms. ${ }^{6}$

An early article by the Dutch philosopher, Glastra van Loon, is useful to clarify how an interactional account sees the legal quality of rules. ${ }^{7}$ His argument can be summarized as stating that the normative quality of rules consists in the rule being the determinant of the legitimate mutual expectations of the addressees of

3 The pragmatist underpinnings of the theory will not be discussed here. However, Fuller and Selznick share a philosophical background in the work of classical pragmatist John Dewey. Compare Kristen Rundle, Forms Liberate: Reclaiming the Jurisprudence of Lon L. Fuller (Oxford: Hart, 2012), 46-47; Martin Krygier, Philip Selznick: Ideals in the World (Stanford: Stanford University Press, 2012), 29-30.

4 For a more extensive argument, see Wibren van der Burg \& Sanne Taekema, 'Towards a Fruitful Cooperation between Legal Philosophy, Legal Sociology and Doctrinal Research: How Legal Interactionism May Bridge Unproductive Oppositions,' in Law, Society and Community: Socio-Legal Essays in Honour of Roger Cotterrell, ed. Richard Nobles \& David Schiff (Ashgate, forthcoming 2014).

5 Lon L. Fuller, 'Human Interaction and the Law,' in The Principles of Social Order. Selected Essyas of Lon Fuller, ed. Kenneth Winston (Durham: Duke University Press 1981), 211-46, at 213.

6 Fuller, 'Human Interaction and the Law,' 219-20.

7 Jan F. Glastra van Loon, 'Rules and Commands,' Mind 67 (1958), 514-21. 
the rule. A rule is the basis for legitimately anticipating others' behaviour as governed by the rule. Reference to a rule can distinguish legitimate from illegitimate expectations, and thereby form the basis for legal obligations. ${ }^{8}$ Both Van Loon and Fuller point out that the meaning of rules as creating legitimate interactional expectations centres on the relationship between the participants in interactional practices, those whose conduct is governed by the rules, not on the relationship between ruler and ruled. Here there is an important link to discussions of reciprocity. Reciprocity is often viewed as the reciprocal relationship between the state and citizen, but in the interactionist framework this form of reciprocity comes second to reciprocity in the form of the interactions between people engaged in social practices. It is therefore useful to distinguish between two forms of interaction: horizontal and vertical, both of which play a role in interactionism. ${ }^{9}$ The vertical interactions between rule-giver and citizen consist in 'a cooperative effort' of both to uphold and abide by the rules. ${ }^{10}$ Cooperation in this context does not mean that there is a common project with shared goals, but rather that both sides need to take the other's perspective into account. The maker of rules keeps the expectations of the followers of rules in mind, while citizens interpret rules as they expect officials to interpret them. As Postema argues, Fuller's explanation of vertical interaction is an extension of his broader argument of horizontal interactions between citizens: it is the same kind of interactional expectancy that people have among themselves. ${ }^{11}$ Moreover, the point of making rules is to facilitate and regulate the behaviour of citizens towards each other.

Much of this framework may seem to fit the forms of modern legal positivism that build on the theory of H.L.A. Hart. More particularly, the attention given to the so-called conventionality thesis, namely that the rule of recognition rests on or even consists in a practice of officials, calls upon ideas of conventional agreement that are close to interactional themes. There are, however, two key differences between pragmatist interactionism and legal positivism that should be addressed briefly to clarify my position. ${ }^{12}$ The first difference is that pragmatist interactionists like Fuller, Selznick and myself see law as oriented to a specific end or set of ends. Assuredly, there are variations here, with Fuller highlighting governance by rules and Selznick focussing on legality in the sense of reduction of arbitrariness, whereas I see law as oriented to justice and legality as distinctive values;

9 Gerald Postema, 'Implicit Law,' in Rediscovering Fuller. Essays on Implicit Law and Institutional Design, ed. Willem Witteveen \& Wibren van der Burg (Amsterdam: Amsterdam University Press 1999), 255-75.

10 Lon Fuller, The Morality of Law (revised edition) (New Haven: Yale University Press, 1969), 219.

11 Postema, 'Implicit Law,' 264.

12 The position that comes closest from a conventionalist perspective, is the work of Den Hartogh, who labels his own position as 'anti-positivist' conventionalism. Govert den Hartogh, Mutual Expectations: A Conventionalist Theory of Law (The Hague: Kluwer Law International, 2002), 155. 
nonetheless, we share a value-oriented approach to law. ${ }^{13}$ This entails that the interactional expectancies gain coherence by reference to the values that the law is to serve. ${ }^{14}$ The second difference is that morality plays an irreducible role in the account of law: legitimate expectations about the behaviour of other participants in the practice of law cannot be solely based on legal elements, because law invokes and depends on moral reasons people have to act, and expect others to act, in a specific way. ${ }^{15}$ I hope to show how this works by discussing particular cases.

In the following, I will no longer argue the point abstractly, but show that this view of law enables us to make sense of what goes on in private law. However, a few general points related to my thesis need to be clarified beforehand. I do not claim that all law is social interaction. Law depends on social interactions in two ways: social interactions are a source of law, and social interactions support the normative force of legal norms. That social interactions are a source of law primarily means that not all law is enacted law: there are implicit forms of law, which could be termed interactional law. This means that law is not reducible to interactions, although it may in part be implicit in social practices. Social interactions support the normative force of law, whether it is explicit or implicit, by providing a context of practices which make sense of legal norms. As Postema argues, legal norms need to be roughly congruent with practical social expectations. ${ }^{16}$ Enacted or formal law (i.e., the law made by legal officials such as legislatures and courts) needs to be understood in relation to interactional expectancies, because formal law is in part a codification of the norms implied in these and because enacted law without some support from interactional expectancies cannot function. If I have no reason to believe that you will abide by a formal rule, my reason for abiding by it is diminished. Therefore, I do not claim that enacted private law is meaningless, far from it, but that there are numerous openings in the formal system of private law that make moral values and social interactional norms an integral part of it. Although a system of purely enacted private law is theoretically imaginable, this would not be a viable system in normal societies. Such a view is not only found in interactionism, it also has affinities with forms of legal hermeneutics that are current in the continental doctrine. ${ }^{17}$ My main inspiration from legal doctrine is the work of the Dutch private law theorist, Paul Scholten, who highlights the continuity between moral and legal normativity in judicial inter-

Fuller, Morality of Law, 146; Philip Selznick, 'Sociology and Natural Law,' Natural Law Forum 6 (1961): 94-95; Sanne Taekema, The Concept of Ideals in Legal Theory (The Hague: Kluwer Law International, 2003), 188.

14 Thus, the position can also be characterized as teleological, in the sense of characterizing law "by the aims for which it can be used,' see Den Hartogh, Mutual Expectations, 163.

15 The first and second difference from positivism are linked by the openness of legal values to moral values, see Taekema, Concept of Ideals, 189-91.

16 Postema, 'Implicit Law,' 265.

17 Larenz Josef Esser, Vorverständnis und Methodenwahl in der Rechtsfindung (Frankfurt am Main: Athenäum Verlag, 1970); Jan Vranken, Exploring the Jurist's Frame of Mind: Constraints and Preconceptions in Civil Law Argumentation (The Hague: Kluwer Law International, 2006). 
pretation and an open, contextual approach in which facts and norms are given meaning simultaneously. ${ }^{18}$

\section{The open system of private law}

How does the connection with social practices play out in the domains of tort and contract? Let us first consider tort law. For Dutch lawyers, the facts of the case I presented at the beginning may ring a bell. Another standard case of Dutch tort law is Kelderluik, a case about a cellar trapdoor that was left open. ${ }^{19}$ In this case the Dutch Supreme Court gives a list of pointers for the assessment of a duty of care in dangerous situations, such as the gravity of the danger, the likelihood that people will be careless, the difficulty of taking precautions, etc. It is important to note that the Supreme Court did not set a norm, but gave a series of criteria to assess tort situations. The norm it uses, first formulated by a court in 1919, and codified in the Dutch Civil Code in 1992, is an open one: people commit a tort when they do not act in accordance with the norms of care in society. ${ }^{20}$ Such a norm opens up the formal system to implicit norms tied to social and moral expectations. I have a moral responsibility not to create dangerous situations, while you have a responsibility to be careful. What that entails exactly will depend on the normal ways of doing things in certain circles and social life more generally. There are numerous examples of tort cases that show how a particular assessment of the social and factual context is decisive for awarding a claim about an alleged tort. Although my analysis draws primarily on Dutch cases, a very similar picture arises when cases from other legal traditions are examined. In English and American law, for instance, tort liability is based on the breach of a duty of due care, which resembles the duty of care in Dutch law. The classic Scottish case of Donoghue v. Stevenson is a good example. Mrs Donoghue drank a bottle of ginger beer in which the remains of a dead snail were contained. Because a friend had bought the bottle for her, there was no direct or indirect relation between Stevenson, the producer of the ginger beer, and Mrs. Donoghue. The House of Lords ruled that Stevenson had nonetheless breached a duty of care he owed to consumers of his ginger beer. The opinion of Lord Atkin provided the general norm: 'You must take reasonable care to avoid acts or omissions which you can reasonably foresee would be likely to injure your neighbour. ${ }^{21}$ Here too, the expectations prevalent in social practice are the main determinant of tort liability. Algemeen deel, ed. G.J. Scholten (Zwolle: Tjeenk Willink, 1974).

19 Supreme Court 5 November 1965, NJ 1966/136.

20 More precisely, Art. 6:162 section 2 Civil Code states that conduct may be unlawful if it infringes a legal right, or if it breaches a statutory duty, or if it is contrary to the social obligations posed by unwritten law (In Dutch: 'Als onrechtmatige daad worden aangemerkt een inbreuk op een recht en een doen of nalaten in strijd met een wettelijke plicht of met hetgeen volgens ongeschreven recht in het maatschappelijk verkeer betaamt, een en ander behoudens de aanwezigheid van een rechtvaardigingsgrond.').

21 Donoghue v. Stevenson [1932] UKHL 100. 
The discussion of tort law shows that one of the main links between enacted law and interactional law is the use of open formulations of key norms. In the literature, such norms are sometimes referred to as open norms, but the more common terminology is that of standards as opposed to rules. ${ }^{22}$ The discussion of rules and standards is relevant to the argument here, but has a much broader scope. The distinction between rules and standards also echoes the debate initiated by Ronald Dworkin on rules versus principles. ${ }^{23}$ Since my point here is not so much to prove that principles are part of the law, but rather to argue that a variety of norms prevalent in social practices form interactional law, I will concentrate on the openness towards social practices that is implied in the use of standards in private law. A favoured example to illustrate the difference comes from traffic law, which in most legal systems contains specific rules, for example 'Do not exceed the speed limit of 50 miles per hour,' but sometimes also contains vague standards, for example 'Behaviour that creates danger on the roads is prohibited. ${ }^{24}$ Standards enlist the judgment of their addressees; they require the exercise of a subject's 'practical deliberation. ${ }^{25}$ Although not mentioned much in the rules versus standards debate, such practical and evaluative judgments depend on the interactional practices in which people are engaged. For example, when playing sports, people expect injuries to occur more frequently than in daily life, and will therefore also expect liability for damage in sports to be limited.

Whereas tort law shows the openness of private law, through the use of standards and the importance of social context, quite clearly the case is more difficult to make for contract. I do claim that the openness of contract law is similar to that of tort law, but this first requires a discussion of the interactionist idea of contracts. As explained above, in an interactionist framework two forms of law are recognized: explicit, enacted law and implicit, interactional law. A contract, however, has a hybrid quality: it contains explicit rules laid down by the contractors themselves. On the one hand, it resembles enacted law, because of the explicit rules that are made by the contractors; on the other hand, it seems interactional

22 Two key articles in the debate are usually taken to be Duncan Kennedy, 'Form and Substance in Private Law Adjudication,' Harvard Law Review 89 (1976): 1685-1778; Louis Kaplow, 'Rules Versus Standards: An Economic Analysis,' Duke Law Journal 42 (1992): 557-629. For an application to contract law, see Vanessa Mak, 'Standards in European Private Law: A Model for European Private Law Pluralism', Tilburg Law School Legal Studies Research Paper Series No. 015/2013, at ssrn.com/abstract=2302562.

23 Ronald Dworkin, Taking Rights Seriously (Cambridge, MA: Harvard University Press, 1977), 14-45. The link between the two debates is forged by seeing standards as requiring an evaluative judgment by the interpreter of the standard, which resembles the moral dimension of principles. Compare Jeremy Waldron, 'Vagueness and the Guidance of Action,' NYU Public Law \& Legal Theory Research Paper Series, Working Paper No. 10-81 (2010), at ssrn.com/abstract=1699963, 9. Standards may, however, also be interpreted more broadly as simply being more vague and flexible than rules, see Frederick Schauer, Thinking Like a Lawyer: A New Introduction to Legal Reasoning (Cambridge, MA: Harvard University Press, 2009), 189.

24 An example of such as standard in Dutch law is Art. 5 Wegenverkeerswet: 'Het is een ieder verboden zich zodanig te gedragen dat gevaar op de weg wordt veroorzaakt of kan worden veroorzaakt of dat het verkeer op de weg wordt gehinderd of kan worden gehinderd.'

Waldron 'Vagueness and the Guidance of Action,' 10. 
because it is a horizontal interaction between two individuals without involvement of official authorities. ${ }^{26}$ Even this picture needs to be made more complex. The vertical and horizontal dimensions are not stable: Fuller points out that contract is not as horizontal as it might seem, because it often involves unequal bargaining power which may effectively allow one of the parties to set the contractual rules. ${ }^{27}$ These considerations imply that we cannot say that contracts, simply because they are made on the basis of mutual consent of persons, are automatically a form of interactional law. The starting point must rather be that contracts appear to be formal law in a particular relationship. Rather than use (all) the rules of the Civil Code, parties to a contract (partly) create their own rules.

However, this is not the full picture of what goes on in contractual relationships. The formal written rules of the contract only go so far. Those rules are part of a broader relationship in which things are expected of the other party that are not laid down in the written rules. Again, an example from Dutch law helps to clarify the point.

A case at least as well known to Dutch scholars as Kelderluik is that of Haviltex. ${ }^{28}$ It is a contract case in which two business owners contract about a piece of machinery that one has produced and the other needs for his horticultural enterprise. They make a contract stating that the buyer of the machine has the right to return it before a certain date at a fixed price. The buyer wishes to do so, but the seller refuses to accept the appeal to the contractual clause because he says no reasons were given for returning the machine. Predictably, the buyer held that giving reasons was not a requirement laid down in the contract. The Supreme Court found for the seller because, it stated, it is not just the text of the contract that counts but also the interpretation parties could reasonably give to it in light of the reasonable expectations contractual parties may have of each other. Given the particular relationship in the case, and the limited legal knowledge of the seller, it was reasonable of him to expect a reason for the termination of the contract.

This case is one of the central precedents in Dutch contract law, providing the main doctrine for the interpretation of contracts. What it shows is that the formal rules of a contract, and I think by extension the formal rules of contract law more generally, are embedded in an interactional practice in which people have certain expectations about each other's behaviour which are justified by their history and the larger social circle of which they are part. An example from English law illustrates the point differently. The case of Williams v. Roffey Brothers and Nicholls (Contractors) Ltd concerns a carpenter working for a firm of contractors

26 See Van der Burg \& Taekema, 'Towards a Fruitful Cooperation between Legal Philosophy, Legal Sociology and Doctrinal Research,' section 3.

27 Lon L. Fuller, 'The Role of Contract in the Ordering Processes of Society Generally,' in The Principles of Social Order: Selected Essays of Lon Fuller, ed. Kenneth Winston (Durham: Duke University Press 1981), 169-87, at 172-3. 
renovating twenty-seven apartments. ${ }^{29}$ A total price of $£ 20,000$ had been agreed at the outset. During the course of the project, it became clear that the carpenter could not complete his work on time for the fixed price, and the contractors agreed to pay an extra amount in instalments to enable him to finish the work on time. The carpenter ceased work when payments were not made according to the revised contract. In court, the contractors took the position that the revised contract was unenforceable. Their defence rested on the doctrine of consideration, claiming that there was no new consideration on the part of the carpenter because there was no change of the work to be done. The court dismissed the appeal, arguing that the contractors had in practice secured a benefit, i.e., that the work would be completed, which could be regarded as consideration. The doctrine of consideration is not relevant to the point I want to make, but the case also shows that the court takes the business relationships and ensuing expectations of the two into account. The contractors knew that the carpenter was in financial difficulties because the fixed price was too low, and were prepared to do something in order for him to stay in business. This can be interpreted as an appeal to an underlying norm that the deal needed to be economically viable for both. ${ }^{30}$ Here, as in the Dutch Haviltex case, the context of interactional norms is crucial to determine the precise nature of the contractual agreement. Overall, these cases point to the fact that the formal law of legislatures and courts does not function in splendid isolation; it is linked to social interactions and its force partly depends on what people may expect from each other in that interactional setting.

In the contract setting, the point about the need to consider the interactional context of formal rules becomes very clear when we consider empirical studies of contracts. A classic of legal sociology is Stewart Macaulay's article on contracts in business relations, in which he shows that in many business relationships formal contracts are concluded but disregarded in the everyday dealings between the business partners. ${ }^{31}$ They are also very hesitant to go to court to settle their disputes. The social norms arising from their business practices, more than the formal rules, inform their behaviour. Since Macaulay, socio-legal research about contracts has shown great variety in the formality or informality of rules and in the relationship between enacted, official law and other forms of regulation. ${ }^{32}$ Regarding torts, similar socio-legal research was done by Ellickson, who found that neighbouring farmers hardly ever claimed damages for trespassing cattle, but

29 England and Wales Court of Appeal (Civil division) 23 November 1989 Williams v. Roffey Brothers and Nicholls (Contractors) Ltd, [1989] EWCA Civ 5.

30 My reading of the case builds on Hugh Collins, Regulating Contracts (Oxford: Oxford University Press 1999), 144-8.

31 Stewart Macaulay, 'Non-Contractual Relations in Business: A Preliminary Study,' American Sociological Review 28 (1963): 1-19.

32 Apart from Collins, Regulating Contracts, a key article is Lisa Bernstein, 'Opting out of the Legal System: Extralegal Contractual Relations in the Diamond Industry,' Journal of Legal Studies 21 (1992): 115-57, who points to the formality of the extralegal rules used in the diamond sector. For a more conceptual discussion of these themes, see Barak D. Richman, 'Norms and Law: Putting the Horse Before the Cart,' Duke Law Journal 62 (2012): 739-66. 
kept their own mental accounts on who owed what to whom. ${ }^{33}$ Such research shows the importance of implicit law, ${ }^{34}$ but it also raises interesting questions. Particularly, it points to the diversity of social practices, and a varying relationship between enacted law, other formal legal regulation and implicit interactional law. Many private law theorists would say that formal contracts are crucial for business dealings between strangers. ${ }^{35}$ Similarly, official law may play a more important role when the perpetrator and the victim of a tort do not know each other well, unlike the context of neighbouring farmers. ${ }^{36}$ An interactionist account is therefore sympathetic to anthropological and sociological research that aims to understand social practices in their empirical variations. Such research may provide a good basis to argue that the character of reciprocal relations in many societies is rather different, and possibly more oppressive, than liberal political and legal philosophies assume. ${ }^{37}$ In order to link these empirical studies to the legal theoretical argument, it is useful to make a further distinction clarifying the relationships between enacted and interactional law. Interactional law can be supportive of enacted law, but it can also be an alternative to enacted law. ${ }^{38}$ In this contribution I have focussed on the connection between enacted law and interactional law by showing how enacted law is open to, and needs to be interpreted in the light of, interactional law. In this relationship, the reverse is also true: interactional law needs embedding in enacted law to be efficacious. However, interactional legal practices also develop in parallel to enacted law, providing an alternative way of regulating conduct. Such practices are usually studied under the heading of legal pluralism. ${ }^{39}$ These plural alternatives bring out the variety of formal and informal non-state law. For clarity's sake, I have focussed on the distinctive forms of enacted and interactional law, realizing, however, that there are less clear-cut variations.

\section{Concluding remarks}

Although the account of contracts and torts can only be sketchy within a short article, using concrete cases in which the importance of social context and interactional expectations are acknowledged is one way of showing that there is indeed a continuous 'interaction' between rules of enacted law and the contextually determined norms of informal, interactional law. As a consequence, the dividing line between law and non-law becomes blurred: the norms that arise out of social

34 Within contract theory this is most clearly acknowledged by the theoretical school of relational contract. Next to Macaulay, Ian R. Macneil and Lisa Bernstein are key proponents.

35 See, e.g., Hanoch Dagan, 'Autonomy, Pluralism, and Contract Law Theory,' Law and Contemporary Problems 76 (2013): 19-38, at 28.

36 As Ellickson found when outsiders were involved in disputes, see Order without Law, 95.

37 E.g., Aafke Komter, Social Solidarity and the Gift (Cambridge: Cambridge University Press, 2005).

38 Cf. Richman, 'Norms and Law.'

39 See, e.g., Marc Galanter, 'Justice in Many Rooms: Courts, Private Ordering, and Indigenous Law,' Journal of Legal Pluralism 19 (1981): 1-47. 
practices in contractual and tort contexts are legal, but they are also moral and social. The legal character of such norms becomes a matter of degree, of more or less, rather than being either legal or non-legal. ${ }^{40}$ For the analytically inclined philosopher this may be a bit unsettling, but the functioning of private law is much better accounted for if law is seen as broader than the enacted law of official authorities, including the interactional law of the practices around us.

40 Cf. Sanne Taekema, 'The Point of Law: The Interdependent Functionality of State and Non-State Regulation,' in International Law and Governance, ed. Hanneke van Schooten \& Jonathan Verschuuren (Cheltenham: Edward Elgar, 2008), 56-73. 